\title{
Sustainability of the Smart phone applications usage in rural India -An empirical study
}

\author{
Souvik Roy ${ }^{1 *}$, Dennis Joseph ${ }^{2}$ \\ ${ }^{1}$ Department of Marketing \& Strategy, IBS Hyderabad, IFHE University \\ souvikroy@ibsindia.org \\ ${ }^{2,}$ Department of Operations \& IT, IBS Hyderabad, IFHE University \\ dennisjoseph@ibsindia.org
}

\begin{abstract}
The Indian smart phone applications market is really flourishing with India ranked as number one in terms of the downloads made via Android and Google play store. However the smart phone application penetration is still low in rural India as compared to its urban part. This study is first of its kind which tries to explore two things, one the reasons, why rural Indian market is not growing in terms of smart phone application downloads/usage and second some antecedents that can affect the behavioral intention of rural customers for increased smart phone application usage. For this study authors resorted to ethnographic in-depth interview during pre-test stage followed by collecting of responses through administrated questionnaires in the second part. Around 346 responses were collected from ten villages in Rangareddy district in Telangana state, in India. SEM was used as the statistical tool to run the hypothesis. In terms of smart phone application development, this study is unique one which tries to throw light immensely on how the marketers/developers can increase the sustainability of smart application usage among rural consumers which happens to be an untouched profitable segment till this point of time.
\end{abstract}

Keywords

Smart phone applications, Smart phone, Rural India, Downloadable, UTAUT2 etc

\section{Introduction}

Today smart phones and the applications (in-built and downloadable) in it has become a technology of substantial interest in every people lives at a global level. The multi tasking capability, ease of use, user friendly interface and ability to deliver almost all the necessary functions that was previously performed by the users via desktops has lead to higher user engagement among consumers ( Varnali \& Toker 2010). Today smart phone performs almost all kinds of functions starting from reading newspaper, healthy diet selections, doing exercise, booking cabs, making hotel reservations, listening music and many more. For its ubiquitous nature it is being more and more popular among users. Seeing this increased customer acceptance of smart phone apps among consumers, marketers all over the world are working really hard to develop various kinds of smart phone applications to cater to the demand of this huge profitable market.

According to App Annie index the worldwide mobile application market is expected to grow at 270 percent - from $\$ 70$ billion in 2015 to $\$ 189$ billion by 2020 (venturebeat.com, 2016). The worldwide smart phone application market represented $\$ 108,440$ million out of 2016 , and is required to develop at a CAGR of $19.2 \%$ to reach
$\$ 311,249$ million by 2023 . Constant increment in the smart phone users and the development of special endorser base in the telecom business is driving the market development for the worldwide smart phone application market amid the estimate time frame (statista.com, 2018).

The smart phone applications industry in India is deafening only lately. However, in this shorter time span India has outpaced countries like US, UK by displaying highest growth in the mobile application market in the year 2016 in terms of Google Play downloads (economictimes.indiatimes.com, 2017). Indian users downloaded over 6 billion apps in 2016, up from 3.5 billion in 2015 which was $15 \%$ higher than the overall download of the apps worldwide (ivemint.com, 2017). Currently India is ranked 29th globally by revenue on iOS and Google Play store in 2018 (thehindubusinessline.com, 2018). Application store revenue and downloads in India grew to $140 \%$ and $250 \%$ in 2018 over 2016 by making Indian market ranked 1 globally by combined downloads in iOS and Google Play store (economictimes.indiatimes.com, 2017).

Furthermore the average smart phone user in the nation has 17 applications and the number is near the worldwide average of 25 applications 
(deloitte.com, 2017). According to an investigation by Ericson (2018), Indian clients spend more than 3 hours and 18 minutes on a normal every day on their smart phones and 33\% of that time is spent on applications. It has been seen that there is $63 \%$ ascent in the use of smart phone applications in the previous two years. India has relatively higher Smartphone usage than the United States (US), where the normal time spent on cell phones is 132 minutes out of every day (emarketer.com, 2018).

However the problem is, though the number of smart phone application users in India is going to turn 478 million by June 2018; India's smart phone application penetration is still below 30\%, especially in rural areas (thehindubusinessline.com, 2018). According to a report by IAMAI (2018), India has around 291 million urban and 160 million rural smart phone application users. Irrespective of the government initiatives like Digital India, smaller priced smart phone sets or developing infrastructure for $3 \mathrm{G} / 4 \mathrm{G}$ internet speeds for easy data access and downloading of applications, penetration of smart phone applications and mobile internet still continues to be only17\% in rural India (livemint.com, 2017).

None of the quantitative studies made on smart phone application usage till this far has intended to explore information on the inspirations, wants, and social setting of present and future rural smart phone application user. These sorts of information give a more entire comprehension of the various monetary and social factors that affect gadget entrance, as well as the outline and execution of smart phone empowered applications, administrations, and substance. In this article we intended to research not only the causes of low smart phone applications download/usage cause but also the factors that may help the marketers/application developers to learn more about the rural smart phone application users' behavior and problems so that, they can redress these issues and design their applications which will help in the increase usage of smart phone applications by the rural consumers in a more convenient way and make it a sustainable culture..
In spite of having the huge potential rural India has shown a relatively slower growth on smart phone and smart phone application adoption in the past few years. Right now, rustic India adds to more than $60 \%$ of the nation's GDP and with the stunning increment in web usage, there is required to be a huge uptick in digital commerce through smart phone applications. A report by the IMAI (2018) specified mobile internet and smart phone application users in rural India is only 160 million (youstory.com, 2018). Around 2/3rd of India's population still lives in rural part. Though the adoption of normal mobile headsets has shown tremendous growth but still the Smartphone ownership and usage/downloads of smart phone application users are relatively low in rural India (dazeinfo.com, 2018). In view of the effect of arranged 3G foundation builds, McKinsey predicted that by $2015,41 \%$ of web access in India will be by means of smart phone (Narasimhan 2011,). However in absence of dependable and moderate $3 \mathrm{G} / 4 \mathrm{G}$ framework right now obstructs more extensive smart phone appropriation. Without the higher quality and quicker transmission rates of $3 \mathrm{G} / 4 \mathrm{G}$ (now), quite a number of the premium highlights of a smart phone-, for example, downloadable applications or premium substance - are lost.

Smart phone and smart phone application infiltration tend to clear the way for more prominent entrance in rural India as long as affordable handsets are accessible for the lower income earning population and also the urban sector market almost reaching its saturation point in terms of their Smartphone application usage/downloads (firstpost.com, 2017). In urban India, correspondence, social networking and amusement (recordings, tunes and so forth) are the best utilizations of mobile web, while in rural India; entertainment controls the perch with social networking and correspondence being alternate administrations arranged by inclination (qz.com, 2016). Rustic mobile web clients developed by an amazing 93\% between December 2014-December 2015 , yet just nine percent of the vicinity has an access to the technology. In contrast, $53 \%$ of urban regions had mobile web network and developed at $71 \%$ amid a similar period, along 
these lines featuring the urban-rustic gap in the nation (gadgetsnow.com, 2016).

\section{Literature Review}

Literature on communication has identified various ideas representing use expectation of a new innovation, Diffusion of Innovation theory (DIT) is a classic example of it (Rogers, 1995). Several distinctive approaches enhancing DIT were presented in terms of human attributes adding to the adoption of innovation including functionality. Social cognitive theory (SCT) (Bandura \& Wessels, 1997) and the theory of planned behavior (TPB) (Ajzen, 1991; Fishbein and Ajzen, 1980) keep up those dispositional factors - attitude, personal networks, and selfefficacy - that embrace the intention to adopt a new innovation. Later on Davis in his Technology adoption model (TAM) explained factors influencing adoption of information and computer technologies (ICTs). The TAM model combined the variables of perceived usefulness and easiness from Diffusion of Innovation theory and attitude, behavioral intention, and actual behaviors from the Theory of Planned behavior. TAM model explained how perceived ease of use and perceived usefulness affects behavioral intention which leads to actual system usage at the end (Davis, 1989).

The latest theory about ICT adoption was drawn from the exacerbating elements of DIT, SCT, the $\mathrm{TPB}$, and the TAM popularly known as the unified theory of acceptance and the use of technology (UTAUT). The UTAUT extends the TAM model by fusing different components that can best clarify the selection procedure. The theory incorporates the ideas of dispositions, social influence, and self-adequacy from SCT and the TPB, compatibility from DIT, and effortlessness/easiness from the TAM. Venkatesh et al. (2012) extended UTAUT to UTAUT2 by adding habit (HA), hedonic motivation (HM), and price value (PV) to it. Since the variance explained in Behavioral intention was better yielded byUTAUT2 than UTAUT (Venkatesh et al., 2012) it makes UTAUT2 a better model (Maurits, 2011) and increases its justification to be used in this research paper for exploring the applicability of UTAUT2 in the area of Smartphone applications.

Performance expectancy was defined as "the degree to which using a technology will provide benefits to consumers in performing certain activities" (Venkatesh et al., 2012, p. 159). Pynoo et al. (2011) featured that performance expectancy is the blend of perceived usefulness from TAM and different constructs related to helpfulness of an innovation in different models. In addition, Pikkarainen et al., 2004, suggested that the worthiness of framework increments if customers find that it is easy to learn and utilize that particular framework. In past performance expectancy has been demonstrated to have a huge positive association with behavioral intention (Chong 2013; Venkatesh et al., 2012 \& Luo et al., 2010). Performance expectancy in correspondence innovation suggests that clients/users consider the smart phone application to be valuable since it empowers them to achieve their objective situated errands (Venkatesh et al., 2003). Past researches have inferred that clients are eager to pay for smart phone application, since they discover qualities and advancements from those applications (Palit et al., 2011). Smart phone application can give valuable capacities to smart phone users, for example, applications that can lead clients/users to their desired usage goal. Along these lines, if a client/user finds that smart phone applications are valuable, at that point the person would have higher expectation to utilize those applications. Hence based on the above discussion we are proposing the following hypothesis:

H1: Performance expectancy significantly affects the behavioral intention of rural users to use Smartphone apps.

Price value has been defined as "consumers' cognitive trade-offs between the perceived benefits of the applications and the monetary cost for using them" (Venkatesh et al., 2012, p. 161). Product price has been recognized as a critical component influencing selection of creative item like smart phone apps. Cleland and Bruno (1997) indentified that product price and another angle, for example, product and non-product viewpoint 
are considered by a purchaser for an obtaining a product. Wickliffe and Pysarchik as referred to by Tariq et al (2013) recommended that intricate item qualities as those imperative features which has concentrated impact on the conduct of the shoppers i.e. brand and price. Shoppers commonly search for low priced brands or substitutes to get the best value (Swani and Yoo, 2010). According to (Crilly et al., 2004; Mohd Azam et al., 2012; Sulistyari, 2012), price is an imperative variable in promoting, where price can impact shopper in making choice to buy an item. Price value is actually based on the concept of perceived value (Venkatesh et al., 2012), which is too assessing and contrasting the view of relative prizes got and the related penances paid (Zenithal, 1988). Past researches have already proved that price value significantly affects the behavioral intention of purchasers (Hanafizadeh et al. 2014; Venkatesh et al. 2012). Whenever perceived benefits exceed the money related penances paid for IT applications, this could impact the innovation use (Venkatesh et al., 2012). In this manner, if a buyer sees that the advantages and preferences got from the use of the application exceed the cost paid, the person would have the expectation to purchase and use it (Hew et al., 2015). Hence based on the above discussion we are proposing the following hypothesis:

$\mathrm{H} 2$ : Product price significantly affects the behavioral intention of rural users to use Smartphone apps.

Social influence was defined by Venkatesh et al. (2012, p. 159) as the "the extent to which consumers perceive that important others (e.g. family and friends) believe they should use a particular technology". Wei et al. (2009) specified that social influence can be classified into two broad categories: mass media impact and relational impact. Papers, scholarly diaries, magazines, web, radio, TV, and other pertinent mediums are under the class of mass media impact; while relational impact ordinarily results from informal organizations for example, peers, companions, bosses, etc. Social influence identified with an individual may make someone else change his or her emotions, mentalities, and conduct, purposefully or unexpectedly (Rashotte,
2007). A shopper conduct is affected by social variables, for example, the customer's little gatherings, family, and social roles and status" (Kotler and Armstrong, 2010). Past researches has already proved that social influence significantly affects the behavioral intention of purchasers (Leong et al. 2013; Chong et al. 2012; Chong 2013). During the decision making process, purchasers will in general tend to get influenced by the social gathering, which is the general population. Contingent upon different components, purchasers may tune in and put stock in various social gatherings, maybe to the individuals who are progressively proficient in specific fields. Clients/users are concerned about whether their companions like the smart phone application they are as of now utilizing and would purchase/download an application in the event that it helped them to fit in with their social gathering. Smartphone application being a technological apparatus may be influenced by not only its technological characteristic, but also consumers' characteristic for example social influence (Leong et al., 2013). Moreover, since smart phone applications are not just usable by specific gatherings of client and its utilization is obligatory (in view of one's will), it is quite possible that the clients/users of smart phone apps are shaping the behavioral intention on the social influence (Hew et al., 2015). Hence based on the above discussion we are proposing the following hypothesis:

H3: Social influence significantly affects the behavioral intention of rural users to use Smartphone apps.

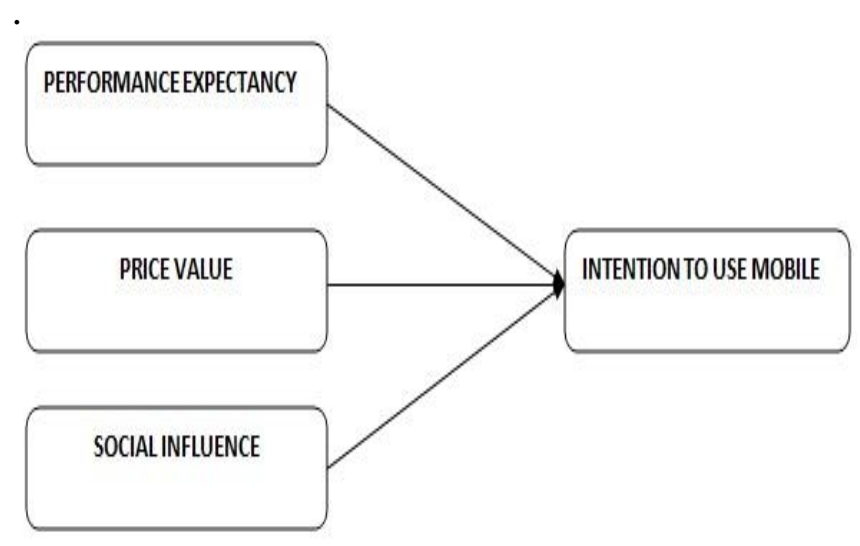

Figure 1: Research Model 


\section{Methods}

The objective of this study was to find out whether smart phone application usage in rural India is as predominant as of the urban India. Accordingly a questionnaire was developed to capture basic information regarding Smartphone ownership and Smartphone application usage amongst rural Indian consumers. This questionnaire was then administered in 10 villages close to Hyderabad city in Telangana state India, viz Khanapur, Anajpur, Jupal, Chandanagar, Kollur, Laskerguda, Chanvelly, Gollapally, Moinabad, and Jawaharnagar. Responses were collected from the respondents in two phases. First an ethnographic in-depth interview was conducted at the house of the respondent's. Questions were intended to accumulate reactions on the basic day by day hones that confined how respondents access, utilize, and make streams of data, information, excitement, and social associations. In the next stage a structured questionnaire were circulated to explore the antecedents affecting the Smartphone applications penetration among the targeted customers. To obtain responses on the questionnaire, village Panchayat Pradhan, teachers of local village school and local informants were met. It was anticipated that probability of ownership of a Smartphone/usage of smart phone applications of this group will be higher than other groups since Smartphone app usage requires Basic English literacy and being a luxury item Smartphone ownership requires moderate to higher income levels. Totally 512 responses were collected, out of which only 346 were found to be usable. Structural equation modelling (Amos. 20) was used a statistical tool for testing significance of the proposed hypothesis. Please refer to table 1 for summary details of survey conducted.

Table 1: Demographic profiles of respondents

\begin{tabular}{|c|c|c|c|}
\hline Item & $\begin{array}{c}\text { Characteristi } \\
\text { cs }\end{array}$ & $\begin{array}{c}\text { Frequen } \\
\text { cy }\end{array}$ & $\begin{array}{c}\text { Percenta } \\
\text { ge }\end{array}$ \\
\hline Gender & Male & 211 & 61 \\
\cline { 2 - 4 } & Female & 135 & 39 \\
\hline Education & $\begin{array}{c}\text { No College } \\
\text { Degree }\end{array}$ & 233 & 68 \\
\hline
\end{tabular}

\begin{tabular}{|c|c|c|c|}
\hline & Diploma & 84 & 24 \\
\hline & Graduate & 29 & 8 \\
\hline & $\begin{array}{c}\text { Post } \\
\text { Graduate/Ph } \\
\text { D }\end{array}$ & 0 & 0 \\
\hline \multirow[t]{5}{*}{ Age } & $\begin{array}{c}\text { Below } 20 \\
\text { years }\end{array}$ & 112 & 32 \\
\hline & $\begin{array}{c}\text { 20-30 years } \\
\text { old }\end{array}$ & 106 & 31 \\
\hline & $\begin{array}{c}\text { 30- } 40 \text { years } \\
\text { old }\end{array}$ & 69 & 20 \\
\hline & $\begin{array}{c}40-50 \text { years } \\
\text { old }\end{array}$ & 47 & 14 \\
\hline & $\begin{array}{c}\text { More than } \\
50 \text { years }\end{array}$ & 12 & 3 \\
\hline \multirow[t]{4}{*}{ Occupation } & $\begin{array}{c}\text { Self - } \\
\text { employed- } \\
\text { agriculture }\end{array}$ & 103 & 30 \\
\hline & $\begin{array}{c}\text { Self } \\
\text { employed- } \\
\text { non- } \\
\text { agriculture }\end{array}$ & 51 & 15 \\
\hline & $\begin{array}{c}\text { Regular } \\
\text { waged/salari } \\
\text { ed } \\
\end{array}$ & 121 & 35 \\
\hline & Others & 71 & 20 \\
\hline \multirow[t]{2}{*}{$\begin{array}{c}\text { Smart } \\
\text { phone } \\
\text { ownership } \\
\end{array}$} & Yes & 103 & 30 \\
\hline & No & 243 & 70 \\
\hline \multirow[t]{2}{*}{$\begin{array}{c}\text { App } \\
\text { usage(Wha } \\
\text { ts app, } \\
\text { Facebook, } \\
\text { e- } \\
\text { seva,mKisa } \\
\text { n) }\end{array}$} & Yes & 41 & 40 \\
\hline & No & 62 & 60 \\
\hline
\end{tabular}

\section{Demographic characteristic of respondents:}

Table 1 shows the demographic characteristic of respondents. The percentage of male and female are 61 and 39 per cent, respectively. Majority of the students are 20-25 years old. $68 \%$ of the respondents did not have any college degree. $24 \%$ of the respondents had a diploma and only $8 \%$ had a graduate degree. It was also seen that no one had 
post graduate or $\mathrm{PhD}$ level of education. More than $60 \%$ of the respondents were below 30 years of age, with half of them below 20 years. There were 69 respondents $(20 \%)$ who where in the age range of 30-40 years and $47(14 \%)$ were in the age group of 40-50 years. Twelve people (3\%) were more than 50 years old. Around 103 respondents were found to be self employed agriculture while 51,121 and 71 respondents were found to be of self employed non-agriculture, salaried and others.

Statistical analysis: The research model shown in Figure: 1 was examined using structural equation modelling with the help of Amos version 20. Covariance based SEM was opted as there was a sufficiently large sample size with regard to the number of items used in the study Chin et al. (2003). In SEM, confirmatory factor analysis (CFA) is used to analyze the measurement model and path analysis is used to analyze the structural model. The measurement model defines relations between the observed and unobserved variables. It specifies the pattern by which each measure loads on a particular factor. It is used only for validating the model and not for explaining the relationships between constructs. It represents how the measured variables come together to represent constructs and is used for validation and reliability checks. Here the construct validity and reliability are established first, after which the model fit indices are examined.

\section{Construct Reliability and Validity}

Construct reliability is a measure of the internal consistency of the observed indicator variables. It determines whether all the measures are consistently representing something. Construct validity refers to the extent to which items or indicators measure a construct as the theory defines. It is established by examining convergent and discriminant validity. Convergent validity checks for the correspondence or convergence between similar constructs, whereas discriminant validity checks the discrimination between dissimilar constructs. For a construct, construct reliability (CR) is calculated from the square of the sum of factor loadings of each construct and the sum of the error variance terms. Nunnally \& Bernstein (1994) stated that CR larger than 0.70 can be regarded as a benchmark for acceptance.
For this study, the derived values of $\mathrm{CR}$ are shown in Table 2, which range from 0.745 to 0.937 .

Table 2: Construct Reliability

\begin{tabular}{||l||l||}
\hline Construct & Reliability \\
\hline \hline Performance Expectancy & 0.937 \\
\hline \hline Price Value & 0.891 \\
\hline \hline Social Influence & 0.800 \\
\hline \hline Intention to use & 0.745 \\
\hline
\end{tabular}

Fornell \& Larcker (1981) proposed that convergent validity may be ascertained by examining the standardized factor loadings and the average variance extracted (AVE). Standardized factor loading with a value of 0.5 or greater is required to ensure convergent validity (Fornell \& Larcker, 1981; Hair, 2010). Average variance extracted should have a value of 0.5 or higher to signify convergent validity (Fornell \& Larcker, 1981). The loadings and AVE values derived for the constructs are given in Table 3. It can be seen that all the factor loadings are above 0.7 and all the AVE values are greater than 0.5.

Table 3: Convergent Validity

\begin{tabular}{|l|l|l|l|}
\hline Construct & Items & Loadings & AVE \\
\hline Performance & PE1 & 0.801 & 0.863 \\
\cline { 2 - 3 } Expectancy & PE2 & 0.885 & \\
\cline { 2 - 3 } & PE3 & 0.873 & \\
\cline { 2 - 3 } & PE4 & 0.896 & \\
\hline Social Influence & SI1 & 0.821 & \multirow{4}{*}{0.780} \\
& Si2 & 0.827 & \\
\cline { 2 - 3 } & SI3 & 0.781 & \\
\cline { 2 - 3 } & Si4 & 0.694 & \\
\hline Price Value & P1 & 0.807 & \multirow{4}{*}{0.770} \\
\cline { 2 - 3 } & P2 & 0.724 & \\
\cline { 2 - 3 } & P3 & 0.779 & \\
\hline Intention to use & USE1 & 0.802 & \multirow{4}{*}{0.792} \\
\cline { 2 - 3 } & USE2 & 0.780 & \\
\cline { 2 - 3 } & USE3 & 0.732 & \\
\cline { 2 - 3 } & USE4 & 0.853 & \\
\hline
\end{tabular}

Discriminant validity measures the extent to which constructs differ (Teo et al., 2009). To ensure discriminant validity, squared interconstruct correlations have to be compared with the average variance extracted (Fornell \& Larcker, 1981). To achieve discriminant validity, the diagonal values should be bigger than the non- 
diagonal values (Kesharwani \& Tiwari 2011). The correlation matrix of constructs, where all squared inter-construct correlations are less than the AVE estimates for each construct in the pair. Therefore discriminant validity is supported for the measurement model.

\section{Goodness of model fiit}

The most important aspect of CFA is to test the 'goodness of fit' of a model. In this study, six different indices are analyzed to examine model fit; they are the Chi-square to its degree of freedom $\left(\chi^{2} / \mathrm{df}\right)$, Normed Fit Index (NFI), Comparative Fit Index (CFI), Tucker-Lewis Index (TLI), Root Mean square Residual (RMR) and the Root Mean Square Error of Approximation (RMSEA). The goodness of fit statistics is reported in Table 4.

Table 4: Goodness of model fit

\begin{tabular}{|c|c|c|}
\hline $\begin{array}{ll}\text { Model } & \text { Fit } \\
\text { Indices } & \end{array}$ & Recommended Value & $\begin{array}{l}\text { Obtained } \\
\text { Value }\end{array}$ \\
\hline$\chi 2 / \mathrm{df}$ & $\begin{array}{l}<3 \text { (Carmines \& Mclver, } \\
1981 \text { ) }\end{array}$ & 1.536 \\
\hline NFI & $>0.9,<1$ (Bentler, 1990) & 0.902 \\
\hline CFI & $\begin{array}{l}>0.95,<1 \mathrm{Hu} \& \text { Bentler } \\
(1999)\end{array}$ & 0.963 \\
\hline TLI & $\begin{array}{l}>0.9,<1 \text { (Hu \& Bentler, } \\
1999)\end{array}$ & 0.958 \\
\hline RMR & $\begin{array}{l}<0.05 \\
1999)\end{array} \quad$ (Hu \& $\quad$ Bentler, & 0.049 \\
\hline RMSEA & $\begin{array}{l}<0.05 \\
1999)\end{array}$ (Hu \& $\quad$ Bentler, & 0.038 \\
\hline
\end{tabular}

\section{Path Analysis}

In multiple linear regression, a squared multiple correlation or $\mathrm{R}^{2}$ for the regression equation indicates the proportion of variance of the dependent variable explained by the independent variables. AMOS software also produces the same $\mathrm{R}^{2}$ statistic with the similar interpretation. The only difference is that AMOS generates $\mathrm{R}^{2}$ for multiple equations rather than for a single equation. The values of squared multiple correlations $\left(\mathrm{R}^{2}\right)$ for the dependent variable is 0.332. They show how much of the variance in these variables have been explained by the predictor or independent variables.

The path coefficient of the path from 'Performance Expectancy' to 'Intention to use' is 0.188 , which is positive and significant ( $p$ - value $<0.01)$. So, the hypothesis $\mathrm{H}_{1}$ is supported. The relationship between 'Price Value' and 'Intention to use' $\left(\mathrm{H}_{2}\right)$ is also significant ( $\mathrm{p}$ value $<0.01$ ) with a $\beta$ value of 0.163 . So, the hypothesis $\mathrm{H}_{2}$ is also supported. In this study, the structural path from 'Social Influence' to 'Intention to use' has a $\beta$ value of 0.148 which is positive and highly significant ( $p$-value $<0.001$ ). So, the hypothesis $\mathrm{H}_{3}$ is also supported.

\section{Discuission}

This study was conducted to find out the causes for low Smartphone application usage and the factors that can influence the betterment of the behavioral intention to use and download Smartphone applications by rural consumers in Indian context. The findings have shown that there is negligible smart phone ownership and smart phone application usage in rural India. As per respondents when asked for their opinion regarding such low rate of adoption and usage of smart phone and smart phone applications, ignorance about the availability of low priced smart phones was cited as one the main reason by most. With majority of people still uneducated, the reason for such ignorance regarding smart phone /smart phone applications usage was found to be obvious. Poor English understanding and operation of the smart phone applications/smart phones also seemed to be an added problem. Though the male respondents has outperformed the female respondents in terms of their smart phone/smart phone applications usage but still a majority of the respondents irrespective of their gender seemed to use their phone for calling, texting and watching videos mainly rather than using it for other purposes like: social networking, gaming, listening to music, following governmental news etc specially the senior respondents above 40 years. On the other side respondents belonging to the age bracket of 20-40 years who are mostly recognized as the heavy users of smart phone/smart phone applications as per IAMAI report 2017, was seemed to be the only one, having knowledge about some of the trendy applications operated through internet like Whatsapp, Facebook, Instagram, YouTube etc. and being the active users of them also. Exceptions were the Village Panchyat Pradhan and the school teachers who also seemed to have 
knowledge about other smart phone applications especially the government ones. Then coming to the livelihood factor, a major percentage of educated rural people seemed to have migrated to urban areas for earning their livelihood, as farming was no longer seen as the main earning option for them. Lastly, lack of infrastructure regarding data speeds, quality of data, data plan, and availability of the different types of productive smart phone applications in terms of their source was also cited as one of the reason for poor smart phone/smart phone applications usage. Most importantly economic barrier still remains to dictate the rural areas with majority of people found to be living below poverty level.

As per the antecedents and their effect on continuous usage and downloads of Smartphone applications is concerned. The entire set of hypotheses was found to have a significant effect in their contribution towards behavioral intention to use and download Smartphone applications. Three primary variables from UTAT2 was used as motivational factors leading to the continuous usage of Smartphone applications namely performance expectancy (PE), Price value (PV) and social influence (SI). The final model outcomes accounts for some unique characteristics that can leveraged by the smartphone application developers/designers in developing the respective Smartphone applications.

In our study perceived expectancy was found to be significant to behavioral intention which is actually consistent with the study of Luo et al., 2010 as rural people might use and download smart phone applications if they find them useful in their daily life signifying usefulness as one of the factors influencing adoption intention (Leong et al., 2013). Price value was also found to have a significant effect on behavioral intention which was consistent with the study of Venkatesh et al., 2012. Rural consumers would intent to use and download smart phone applications if they perceive the benefits received is greater than the money paid for the smart phone applications. Lastly social influence was too found to have a significant influence in consistent with the earlier studies (Chong 2013; Chong et al., 2012). This proposed hypothesis implied that important people surrounding the rural consumers would exert positive influence in their continuous usage/download behavior of the smart phone applications.

\section{Implications and limitations}

This study mainly articulated both qualitative and quantitative point of view by discussing the social, economic, cultural and administrative factors on one side and proposing certain antecedents through exhaustive literature review and empirically testing them on the other side which if looked and addressed properly by the marketers/developers can help them to turn rural Indian customer base into a profitable segment in terms of smart phone application downloads/usage. Firstly, from the qualitative survey majority of the rural customers being middle class and lower middle class, their price sensitive behavior can provide immense opportunity to low priced handset makers for rolling out cheap Smartphone devices along with easy data plan connections provided by the current big telecom giants. Vice versa the $4 \mathrm{G}$ data service providers are also looking for penetration in rural markets which is only possible if low priced smart phone devices are available along with localized content and relevant services. Specialists say the passage of virtual network administrators may likewise go about as an impetus in the reception of $4 \mathrm{G}$ smart phones in provincial regions which in turn will lead to the usage and downloading of smart phone applications. However looking at the current telecom infrastructure in rural market, neither the speed nor the quality of the data plan seems to be appropriate hence, quite a bit of work needs to done on the present structure before moving into next higher speed domains. Secondly ,as awareness about the smart phone and the smart phone applications usage is still a persisting problem in rural India, displays in temporary formed kiosks/or local kirana stores by the marketers, and explaining/educating the rural customers about the various smart phones/applications and their respective usage will be of great help. Banner ads in local languages and personal selling of smart phones on easy monthly installment basis can also be thought of as an option by the marketers. Then targeting the influencer and the opinion leader in terms of decision making regarding the smart phone applications usage makes quite an important 
strategy for the marketers in terms of rural consumers as few important persons like the Village (Gram) Panchayat Pradhan, School teachers, person representing social class group do play an important role in influencing the decision of the village consumers in terms of product/service usage. Lastly though the marketer's role in the design, promotion and pricing the smart phone applications is crucial but the services of the Government agencies for creating the awareness and increasing the smart phone application usage/downloads in rural sector can't be ignored. The digital divide has to be decreased through campaigns like Digital and Smart India in a more effective way. Hence there is great opportunity for the marketers to design such kind of smart phone applications that can cater to the need of the rural market as well fetch them potential amount of profit. India's rustic populace is almost double that of urban. With advancement of grabbing speed in country India, combined with increment in rural acquiring power, this purchaser portion has a gigantic potential to blossom into a strong business opportunity. Be that as it may, rustic customers are a heterogeneous parcel with differing needs and comprehension of digital media. Successful advanced promoting systems should focus around right measuring and client segmentation to enhance return on investments of marketing campaigns.

From the empirical point of view this study has used UTAUT2 model to explain the factors affecting the behavioral intention of the rural consumers to use/download smart phone applications. All the variables used in study surely throws an insight regarding the aspects smart phone application developers/marketers has to look forward for designing their applications in a better way from the rural consumers point of view. In terms of PE the developers has look at the daily lives of the rural consumers and see how they can design the applications so that they can use them for performing various functions related to their routine lives. As provincial showcasing is to a great extent smart phone application driven, streamlining publicizing efforts for mobile inquiry, local languages, responsive layout, easy navigation, and user-friendly content ought to be key central focuses. For PV the marketers/developers can opt for other revenue models rather than making the applications paid at the very first place. And lastly for SI the identification of influential persons in rural areas is very crucial as they can in turn prove to be a positive influence in the decision making process of the rural consumers. So targeting those influential persons and promoting the applications first to them should be done on a priority basis.

Though this study has contributed many dimensions of rural consumer's smart phone application behavior but still being conducted in India it may not reflect the picture of other nations around the globe. In future a study regarding this will be of immense value for both the marketers as well as the academicians. Secondly relative study of rural consumers across more states in India itself will be of great help to generalize the study results in a more significant way as increasing the sample frame will facilitate to remove the sample constraints. Lastly an experimental study in future by developing smart phone applications with the all the embedded features as per their feedbacks of the rural consumers and capturing their reaction towards them will also help the marketers in designing their applications suitably.

\section{References (APA $6^{\text {th }}$ edition)}

1. Ajzen, I. (1985). From intentions to actions: A theory of planned behavior. In Action control (pp. 11-39). Springer, Berlin, Heidelberg.

2. Anam, C. (2014). The Impact of Social Influence, Compatibility and Price on Purchase Intention of Android Android Smartphone (Doctoral dissertation, Universitas Muhammadiyah Surakarta).

3. Palit, R., Arya, R., Naik, K., \& Singh, A. (2011, May). Selection and execution of user level test cases for energy cost evaluation of smartphones. In Proceedings of the 6th International Workshop on Automation of Software Test (pp. 84-90). ACM.

4. Bandura, A. (1997). Editorial. American Journal of Health Promotion, 12(1), 8-10. 
5. Bloch, P. H. (1995). Seeking the ideal form: Product design and consumer response. The Journal of Marketing, 1629.

6. Chin, W.W., Marcolin, B.L., \& Newsted, P.R. (2003). A partial least squares latent variable modeling approach for measuring interaction effects: Results from a Monte Carlo simulation study and an electronicmail emotion/adoption study. Information Systems Research, 14(2), 189-218.

7. Chong, A. Y. L. (2013). Predicting mcommerce adoption determinants: A neural network approach. Expert Systems with Applications, 40(2), 523-530.

8. Crilly, N., Moultrie, J., \& Clarkson, P. J. (2004). Seeing things: consumer response to the visual domain in product design. Design studies, 25(6), 547-577.

9. Davis, F. D. (1989). Perceived usefulness, perceived ease of use, and user acceptance of information technology. MIS quarterly, 319-340.

10. Fishbein, M., \& Ajzen, I. (1975). Belief, attitude, intention and behavior: An introduction to theory and research.

11. Fornell, C., \& Larcker, D. F. (1981). Structural equation models with unobservable variables and measurement error: Algebra and statistics. Journal of marketing research, 382-388.

12. Hair, J. F. (2010). Black, WC, Babin, BJ, \& Anderson, RE (2010). Multivariate data analysis, 7.

13. Hanafizadeh, P., Behboudi, M., Koshksaray, A. A., \& Tabar, M. J. S. (2014). Mobile-banking adoption by Iranian bank clients. Telematics and Informatics, 31(1), 62-78.

14. Hew, J. J., Lee, V. H., Ooi, K. B., \& Wei, J. (2015). What catalyses mobile apps usage intention: an empirical analysis. Industrial Management \& Data Systems, 115(7), 1269-1291.

15. Kesharwani, A., \& Tiwari, R. (2011). Exploration of internet banking website quality in India: a webqual approach. Great Lakes Herald, 5(1), 4058.
16. Kotler, P., \& Armstrong, G. (2010). Principles of marketing. Pearson education.

17. Leong, L. Y., Ooi, K. B., Chong, A. Y. L., \& Lin, B. (2013). Modeling the stimulators of the behavioral intention to use mobile entertainment: does gender really matter?. Computers in Human Behavior, 29(5), 2109-2121.

18. Luo, X., H. Li, J. Zhang and J. P. Shim (2010). "Examining multi-dimensional trust and multi-faceted risk in initial acceptance of emerging technologies: An empirical study of mobile banking services", Decision Support Systems, Vol. 49, No 2: 222-234

19. Mohd. Azam., Talib, A. Z., Sanusi, Z. A., Shiang-Yen, T., \& Alwi, A. S. (2012). A Study of the Trend of Smartphone and its Usage Behavior in Malaysia. International Journal of New Computer Architectures and their Applications, 2(1), 275-287.

20. Maurits, N. (2011). From neurology to methodology and back: an introduction to clinical neuroengineering. Springer Science \& Business Media.

21. Narasimhan, L. (2011). Can India lead the mobile-Internet revolution? McKinsey Quarterly, 5.

22. Narasimhan, Laxman. (2011). Can India lead the mobile-Internet revolution? McKinsey Quarterly, McKinsey \& Company.

23. Nunnally, J.C., \& Bernstein, I.H. (1994). Psychometric theory. New York, NY: McGraw-Hill.

24. Pikkarainen, T., Pikkarainen, K., Karjaluoto, H., Pahnila, S., 2004, "Consumer acceptance of online banking: an extension of the technology acceptance model", Internet Research, Vol. 14, No. 3, pp. 224-235.

25. Pynoo, B., Devolder, P., Tondeur, J., van Braak, J., Duyck, W., \& Duyck, P. (2011). Predicting secondary school teachers' acceptance and use of a digital learning environment: a crosssectional study. Computers in Human Behavior, 27(1), 568-575. 
26. Rashotte, L. (2007). Social influence. The Blackwell encyclopedia of sociology.

27. Rogers, E. M. (1995). Diffusion of innovations (4th ed.). New York: The Free Press

28. Rogers, E. M. 1962. Diffusion of Innovations. New York: Free Press

29. Sulistyari, I. N., \& YOESTINI, Y. (2012). Analisis pengaruh citra merek, kualitas produk, dan harga terhadap minat beli produk oriflame (studi kasus mahasiswi Fakultas Ekonomika dan Bisnis Jurusan Manajemen Universitas Diponegoro Semarang) (Doctoral dissertation, Fakultas Ekonomika dan Bisnis).

30. Swani, K., \& Yoo, B. (2010). Interactions between price and price deal. Journal of Product \& Brand Management, 19(2), 143-152.

31. Tariq, M. I., Nawaz, M. R., Nawaz, M. M., \& Butt, H. A. (2013). Customer perceptions about branding and purchase intention: a study of FMCG in an emerging market. Journal of Basic and Applied Scientific Research, 3(2), 340-347.

32. Teo, T. T., Lee, C. B., \& Chai, C. S. (2008). Understanding pre-service teachers' computer attitudes: applying and extending the technology acceptance model. Journal Of Computer Assisted Learning, 24(2), 128-143

33. Varnali, K., \& Toker, A. (2010). Mobile marketing research: The-state-of-theart. International journal of information management, 30(2), 144-151.

34. Venkatesh, V., Morris, M. G., Davis, G. B., \& Davis, F. D. (2003). User acceptance of information technology: Toward a unified view. MIS quarterly, 425-478.

35. Venkatesh, V., Thong, J. Y. L., \& Xu, X. (2012). Consumer acceptance and use of information technology: Extending the unified theory of acceptance and use of technology. MIS Quarterly, 36(1), 157178.

36. www.venturebeat.com, "Mobile app market to grow $270 \%$ to $\$ 189$ billion by 2020 , with games accounting for 55\%", by Dean Takahashi, November 2016.
37. Wei, T.W., Marthandan, G., Chong, A.Y.L., Ooi, K.B. and Arumugam, S. (2009), "What drives Malaysian mcommerce adoption?An empirical analysis.Industrial Management \& Data Systems, Vol. 109 No. 3, pp. 370-388.

38. www. qz.com, "India's rural internet users love Facebook, Whatsapp and free music downloads", By Suneera Tandon, August, 2016

39. www.dazeinfo.com, "Smartphone Users in India", 2018, By Itu Rathore.

40. www.economictimes.indiatimes.com, "India becomes world's fastest-growing market for apps "by J.Vignesh, April, 2018.

41. www.emarketer.com, "Mobile Time Spent 2018Will Smartphones Remain Ascendant? Yoram Wurmser, June 18, 2018.

42. www.ericsson.com, "Mobile subscriptions Q1 2018”, Ericsson Mobility Report, June 2018.

43. www.firstpost.com, "'Mobile internet witnesses faster users growth in rural India", May 2013.

44. www.gadgetsnow.com, "Only 9\% of rural India has access to mobile internet: Report”, Kim Arora, February 2016.

45. www.iamai.in, "Mobile internet report, 2018.

46. www.livemint.com, "Let's make rural India smart, one app at a time, 2017.

47. www.manipalprolearn.com, "Three Ways Digital Marketing Can Up the Indian Rural Banking Game", By Arijit Banerjee, February 2018.

48. www.statista.com, Number of mobile phone users in India from 2013 to 2019 (in millions), 2018.

49. www.thehindubusinessline.com, "Mobile internet users in India seen at 478 million by June', 2018.

50. www.youstory.com, "Mobile internet users in India to reach 478 million by June 2018: IAMAI report.

51. www2.deloitte.com, "Global Mobile Consumer Survey: US edition/ The dawn of the next era in mobile", 2017. 
52. Zeithaml, V. A. (1988). Consumer perceptions of price, quality, and value: a means-end model and synthesis of evidence. The Journal of marketing, 2-22. 